\title{
Influence of Different Habitats on The Chemical Constituents of Codium tomentosum
}

\author{
H.A. Mansour ${ }^{\#}$, M. M. Emam and N.H. Mostafa \\ Department of Botany, Faculty of Sciences, Ain Shams University, 11566, Cairo, \\ Egypt.
}

\begin{abstract}
$\mathbf{T}$ HE CURRENT study was conducted to assess the influence of different harvesting site (habitat) on the chemical constituents of Codium tomentosum Stack collected from two different sites on the coast of Egypt (Mediterranean [M] and Red [R] Seas). The current results showed that, salinity and temperature of the Red Sea is relatively higher than those of the Mediterranean one. Additionally, results indicated significant differences in the biochemical profiles of Codium between the two sampling sites. The total carbohydrate, proline, glycerol content together with total antioxidant capacity, reducing power as well as mineral content $\left(\mathrm{Na}^{+}, \mathrm{K}^{+}\right.$and $\left.\mathrm{Ca}^{++}\right)$and the activities of antioxidant enzymes (PPO, POX, ASO, APX and CAT) of Codium collected from site $\mathrm{R}$ were significantly higher than of those collected from site $\mathrm{M}$. In contrast, total protein, total amino acids, flavonoids contents were predominated in Codium harvested from the Mediterranean Sea. No significant differences in ascorbic acid, glutathione, chlorophyll a content and total phenols collected from the two sites. The electrophoretic analysis of protein pattern revealed the appearance of of 7 and 8 polypeptide bands in Codium from the two sites ( $M$ and $\mathrm{R}$, respectively). However polypeptides with molecular weights 93 , 72 and $42 \mathrm{kDa}$ were recorded only for Codium of site (M), while that of $17 \mathrm{kDa}$ was specific for Codium of site (R). In conclusion, this study shows that the different sampling sites influences on biochemical profiles of Codium. However, Codium in response to extreme temperatures and salinity, may alter its metabolism, building a strong protection system and producing compatible solutes in various ways to overcome these stress. This result is a step towards to study the algal diverse biochemical integrations involved in cellular adaptation of algae to different environmental factors and habitats.
\end{abstract}

Keywords: Seaweeds with seasonal and location variations, Biochemistry of macro-algae, Codium tomentosum, Physico-chemical characters of Mediterranean and Red Seas.

\section{Introduction}

Seaweeds are nutritionally valuable as fresh or dried vegetables, or as ingredients in a wide variety of prepared foods (Robledo \& Pelegrin, 1997). Chemical composition of the macro-algae vary depending on geographical distribution, habitats, maturity, seasons and the principal environmental conditions, such as water temperature, salinity, light, and nutrients (Ortiz et al., 2006 and Messyasz \& Rybak, 2010). Salinity and temperature represents a dominant factor affecting both the local distribution (Leland et al., 2001). Temperature has proved to be of paramount importance (Van den Hoek, 1984), however a certain stage of an algal life cycle usually is sensitive to temperature. Also salinity can act as a limiting factor in the distribution of macro-algal species. Algae have been attracted the attention of scientists specially those growing under salinity stress (Mansour et al., 2017). They can serve as model organisms for a better understanding of salt acclimation in the more complex physiological processes of higher plants (Kakinuma et al., 2006 and Ashraf \& Foolad, 2006). Seasonal and locational changes of chemical composition of Ulva rigida were investigated by İrkin \& Erduðan (2014). However, significant differences were recorded in protein content of the collected species in terms of season and stations.

The North (Mediterranean Sea) and west (Red Sea) coasts of Egypt are rich in macroalgae resources. The green macro-algae (Codium spp.) are the most abundant in these coastal areas (Aleem, 1993 and El-Said \& El-Sikaily, 2013) and in Suez Canal (Farghaly \& El-Shoubaky, 2015) yearly. However, the utilization of this macro

"Corresponding author email: rodynarwan@yahoo.com 
alga in these regions is very restricted. Codium tomentosum is found in many parts of the world, it is also, native to the northeast Atlantic Ocean from the British Isles southwards to the Azores and Cape Verde. Codium tomentosum is used in products from the United States, Germany, Italy, and the UK. Some of these products are repair and restoration moisturizers, hydration serums, eyes and skin creams, anti-aging masks, lip balms, and lotions. It is a popular food in some parts of Asia (Loiseaux-de Goër \& Noailles, 2008).

Numerous studies have demonstrated the biochemical contents of Egyptian seaweeds according to seasonality, but there is no data on the biochemical composition of the same species collected from two different localities. Hence, the current work aim to demonstrate the crucial influence of habitat variation on the biochemical composition of Codium tomentosum selected from the coasts of Mediterranean and Red Seas.

\section{Materials and Methods}

\section{Algal sampling}

Seaweed samples of Codium tomentosum (Chlorophyta: Codiaceae) were hand-picked from Alexandria (Mediterranean Sea) and Hurgada (Red Sea) during 2014. The Collected algal samples immediately washed with the surrounding water to remove extraneous matters, sand particles and epiphytes as much as possible. Then, they kept in ice box containing frozen gel cold packs to maintain the low temperature and moisture during the journey and immediately transported to the laboratory. On arrival samples were thoroughly washed with tap water and finally with distilled water, then spread on blotting paper to remove excess water. Finally, cleaned algal samples were divided into four groups prior to the chemical analysis. In first group, samples were preserved in freezer for fresh weight analysis, second group was shaded air-dried, cut into small pieces and grounded into fine powder using a dry grinder and preserved for dry weight analysis, third group was oven-dried at $80^{\circ} \mathrm{C}$ to constant weight for mineral analysis and the final group was preserved in 4\% formalin for identification (voucher specimens).

Some physico-chemical analysis of sampled water Some physico-chemical charactersof the water samples that collected from Mediterranean and Red Seas were measured according to Jackson \& Thomas (1960).

\section{Biochemical analysis of algae}

Soluble sugars and sugar-free residues were extracted following the method adopted by Homme et al. (1992) and Naguib (1963), respectively. Soluble sugars and those obtained after polysaccharides hydrolysis were estimated using the anthrone reagent as described by Blakeney \& Mutton (1980). Soluble proteins were extracted according to the method described by Daughaday et al. (1952). Meanwhile, the water insoluble residue remaining after extraction of soluble proteins was extracted with $1 \mathrm{~N} \mathrm{NaOH}$. Soluble proteins and those resulting after insoluble residue hydrolysis were measured using BIO-RAD protein assay dye reagent according to the method adopted by Bradford (1976). Total free amino acids were carried out according to Wasfi (1970). Free proline was determined according to the method described by Bates et al. (1973). Glycerol was extracted from algal tissues according to the method adopted by Kochert (1978). Moreover, glycerol content was estimated according to Lambert \& Neish (1950). Sodium, potassium, and calcium were estimated according to the method described by Ranganna (1977) using atomic absorption spectrophotometer (Pekrin Elmer USA 3100). Photosynthetic pigments (chlorophyll a, chlorophyll b and carotenoids) were extracted in $80 \%$ acetone and determined spectrophotometrically as recommended by Metzner et al. (1965).

Antioxidants as glutathione and ascorbic acid were extracted and estimated following the methods described by Hissin \& Hilf (1976) and Mukherjee \& Choudhuri (1983), respectively. The amount of total phenol was determined with the Folin-Ciocalteu reagent using the method of Malik \& Singh (1980) and the absorbance was measured at $765 \mathrm{~nm}$ using spectrophotometer (Spectronic 601, Milton Roy Company). Total flavonoid content can be determined by Aluminum chloride method (Harborn, 1998) and the absorbance was measured at $415 \mathrm{~nm}$. Ferric reducing power (FRAP) was estimated according to Dorman et al. (2003). Moreover, total antioxidant capacity was determined according to the method of Oyaizu (1986). Polyphenol oxidase activity (PPO), peroxidase activity (POX), ascorbate oxidase activity (ASO), ascorbate peroxidase activity (APX) and catalase activity (CAT) were evaluated according to Kar \& Mishra (1976), Diallinas et al. (1997), Koricheva et al. (1997) and Chen et al. (2000), respectively. 
Moreover, the determination, identification and characterization of different protein fractions were obtained using one-dimensional sodium dodecyl sulphate polyacrylamide gel electrophoresis. Polyacrylamide slab gel (12.5\%) was prepared according to Laemmli (1970). The destining gel was analyzed by Gel Documentation System (GDS), model UVP"s GDS 8000 from UVP Inc. (California 91786 USA), to analyze the band pattern, molecular weights and band percentages.

N.B. The biochemical results of Codium tomentosum collected from Mediterranean Sea were cited in M. Sc. Thesis of Mostafa, N.H. (2016) and didn't yet published previously. This thesis was under the supervision of A.M. Shaaban, M.M. Emam and H.A. Mansour.

\section{Statistic analysis}

All determinations were made in triplicate for all assays. Data were subjected to an analysis of variance (ANOVA) with statistical significance at $\mathrm{P}<0.05$ being tested using the Duncan's Test and Pearson correlation.

\section{$\underline{\text { Results }}$}

The results of some physico-chemical characters of sampled water in Table 1 showed no major differences in the chemistry of water between the two studied localities except for salinity and temperature. However salinity and temperature of the Red Sea is relatively higher than those of the Mediterranean one.

TABLE 1. Some physico-chemical characters of sampled water.

\begin{tabular}{lcccc}
\hline \multirow{2}{*}{ Parameters } & \multicolumn{2}{c}{ Red Sea } & \multicolumn{2}{c}{$\begin{array}{c}\text { Mediterranean } \\
\text { Sea }\end{array}$} \\
\cline { 2 - 5 } & Min. & Max. & Min. & Max. \\
\hline Temperature $\left({ }^{\circ} \mathrm{C}\right)$ & 28 & 29.5 & 16.9 & 18.5 \\
Salinity $(\%)$ & 41.7 & 42.2 & 38.4 & 38.9 \\
pH & 8.5 & 8.7 & 8.2 & 8.6 \\
$\begin{array}{l}\text { Dissolved oxygen } \\
(\mathrm{mg} / \mathrm{L})\end{array}$ & 4.9 & 5.8 & 5 & 5.5 \\
\hline
\end{tabular}

Phytochemical evaluation results of Codium tomentosum of Mediterranean Sea (M) and Red Sea $(\mathrm{R})$ coasts were represented in Table 2 . There are significant differences in the biochemical profiles between the two samples. It is clearly obvious that, the total carbohydrate content of Codium collected from R site (359.3 mg. $\mathrm{g}^{-1} \mathrm{fw}$ ) was significantly higher than of those collected from site $\mathrm{M}\left(224.9 \mathrm{mg}^{-g^{-1}} \mathrm{fw}\right)$.

Concerning to protein, the highest content was recorded for Codium collected from Mediterranean Sea $\left(5.9 \mathrm{mg} \mathrm{g}^{-1} \mathrm{fw}\right)$ where as Codium from the Red Sea has the total protein content of $\left(5.4 \mathrm{mg} \cdot \mathrm{g}^{-1} \mathrm{fw}\right)$. In addition the total amino acids showed significant differences between the two sampling sites, $1.8 \mathrm{mg} \cdot \mathrm{g}^{-1}$ fw for samples harvested from site $\mathrm{M}$ and $\left(0.32 \mathrm{mg} \cdot \mathrm{g}^{-1} \mathrm{fw}\right)$ for samples of site R.

Moreover, the mineral compositions (presented by $\mathrm{Na}^{+}, \mathrm{K}^{+}$and $\mathrm{Ca}^{+2}$ ) data were strongly different between the two sampling sites. For $\mathrm{R}$ samples, values were 7.1, 31.6 and $14.2 \mathrm{mg} \mathrm{g}^{-1} \mathrm{dw}$, respectively while, values for $\mathrm{M}$ sample were 2.2, 4.9 and $2.48 \mathrm{mg}^{-1} \mathrm{~g}^{-1} \mathrm{dw}$, respectively. Thereby the mineral composition of Codium collected from Red Sea has a higher value than those collected from Mediterranean Sea.

In respect to the pigments, the results showed that there was no significant difference in chlorophyll a content of Codium collected from both sites while chlorophyll $\mathrm{b}$ and carotenoids were slightly higher in Codium collected from

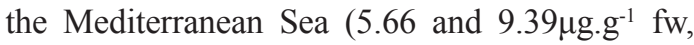
respectively) than the same species collected from

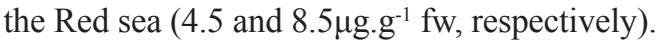

Moreover, it is clearly shown that, glycerol and proline (Table 2) recorded a marked increase in Codium collected from the Red Sea $\left(64.5 \mu \mathrm{M} . \mathrm{g}^{-1} \mathrm{fw}\right.$ and $2.5 \mu \mathrm{g} \cdot \mathrm{g}^{-1} \mathrm{fw}$, respectively) compared to that from the Mediterranean Sea $\left(50.8 \mu \mathrm{M} . \mathrm{g}^{-1} \mathrm{fw}\right.$ and $2.1 \mu \mathrm{g} . \mathrm{g}^{-1} \mathrm{fw}$, respectively). Data in Table 3 indicated that the total phenol content in Codium collected from the R site has the same value $\left(0.39 \mathrm{mg}^{-\mathrm{g}^{-1} \mathrm{fw}}\right)$ as Codium collected from the $\mathrm{M}$ site. However, total flavonoids were strongly different between the two sampling sites, where the maximum value was predominated with Codium harvested from the Mediterranean Sea $\left(10.8 \mathrm{mg}^{-1} \mathrm{~g}^{-1} \mathrm{dw}\right)$ and the minimum value was predominated with Codium harvested from the Red Sea (2.9mg.g $\left.{ }^{-1} \mathrm{dw}\right)$.

In contrast, ascorbic acid and glutathione have more or less significant difference between the two sampling sites. In $\mathrm{M}$ samples, ascorbic acid $\left(0.35 \mu \mathrm{M} . \mathrm{g}^{-1} \mathrm{fw}\right)$ was lower than those of $\mathrm{R}$ 


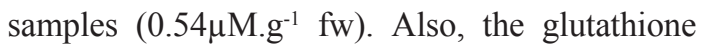
content of $\mathrm{M}$ samples $\left(9.5 \mathrm{mM} \cdot \mathrm{g}^{-1} \mathrm{fw}\right)$ was lower in comparison to $\mathrm{R}$ samples $\left(9.8 \mathrm{mM}^{-1} \mathrm{fw}\right)$. These associated with a greater value in the total antioxidant capacity (Table 3 ) of samples collected from the Red Sea than that collected from the Mediterranean Sea (230.1 and 126.6ìg. $\mathrm{g}^{-1}$ $\mathrm{dw}$, respectively). Moreover, the reducing power (Table 3$)$ of R samples $\left(0.9 \mu \mathrm{g} \cdot \mathrm{g}^{-1} \mathrm{dw}\right)$ recorded a pronounced higher value than of $\mathrm{M}$ samples $\left(0.3 \mu \mathrm{g} \cdot \mathrm{g}^{-1} \mathrm{dw}\right)$.

TABLE 2. Changes in the biochemical composition (carbohydrate, proteins, total amino acids, some minerals and pigments) of Codium tomentosum collected from Mediterranean Sea (M) and Red Sea (R).

\begin{tabular}{|c|c|c|c|c|c|c|c|}
\hline \multirow{3}{*}{\multicolumn{2}{|c|}{ Carbohydrate (mg.g-1 fw) }} & \multicolumn{6}{|c|}{ Biochemical parameters of Codium tomentosum } \\
\hline & & \multicolumn{2}{|c|}{ Total soluble sugars } & \multicolumn{2}{|c|}{ Total insoluble sugars } & \multicolumn{2}{|c|}{ Total sugars } \\
\hline & & M & $\mathbf{R}$ & $\mathbf{M}$ & $\mathbf{R}$ & M & $\mathbf{R}$ \\
\hline & & $0.87 \pm 0.02$ & $1.22 \pm 0.04$ & $224.05 \pm 5.3$ & $358.06 \pm 16.6$ & $224.89 \pm 5.3$ & $359.34 \pm 16.6$ \\
\hline \multirow{2}{*}{$\begin{array}{l}\text { Proteins } \\
\left(\mathrm{mg} \cdot \mathrm{g}^{-1} \mathrm{fw}\right)\end{array}$} & $\begin{array}{c}\text { Total soluble } \\
\text { proteins }\end{array}$ & \multicolumn{2}{|c|}{$\begin{array}{l}\text { Total insoluble } \\
\text { proteins }\end{array}$} & \multicolumn{2}{|c|}{ Total proteins } & \multicolumn{2}{|c|}{ Total amino acids } \\
\hline & M & M & $\mathbf{R}$ & M & $\mathbf{R}$ & M & $\mathbf{R}$ \\
\hline & $3.54 \pm 0.043 .03 \pm 0.05$ & $2.33 \pm 0.06$ & $2.39 \pm 0.14$ & $5.86 \pm 0.1$ & $5.42 \pm 0.14$ & $1.83 \pm .2$ & $0.32 \pm 0.05$ \\
\hline \multirow{3}{*}{\multicolumn{2}{|c|}{ Minerals $\left(\mu \mathrm{g} \cdot \mathrm{g}^{-1} \mathrm{dw}\right)$}} & \multicolumn{2}{|c|}{ Sodium } & \multicolumn{2}{|c|}{ Potassium } & \multicolumn{2}{|c|}{ Calcium } \\
\hline & & $\mathbf{M}$ & $\mathbf{R}$ & M & $\mathbf{R}$ & $\mathbf{M}$ & $\mathbf{R}$ \\
\hline & & $2.20 \pm 0.03$ & $7.10 .035 \pm$ & $4.97 \pm 0.18$ & $31.6 \pm 0.15$ & $2.48 \pm 0.01$ & $14.24 \pm 0.09$ \\
\hline \multirow{3}{*}{\multicolumn{2}{|c|}{ Pigments $\left(\mu \mathrm{g} \cdot \mathrm{g}^{-1} \mathrm{fw}\right)$}} & \multicolumn{2}{|c|}{ Chl. a } & \multicolumn{2}{|c|}{ Chl. b } & \multicolumn{2}{|c|}{ Carotenoids } \\
\hline & & M & $\mathbf{R}$ & M & $\mathbf{R}$ & M & $\mathbf{R}$ \\
\hline & & $3.73 \pm 0.15$ & $3.97 \pm 0.29$ & $5.66 \pm 0.3$ & $4.54 \pm 0.05$ & $9.39 \pm 0.5$ & $8.52 \pm 0.1$ \\
\hline
\end{tabular}

Values (means \pm standard deviation of data for duplicated groups) for each site in the same column are significantly different at $5 \%$ level.

TABLE 3. Changes in the biochemical compositions (proline, glycerol, antioxidants compounds, antioxidants enzymes and antioxidants activity) of Codium tomentosum collected from Mediterranean Sea (M) and Red Sea (R).

\begin{tabular}{|c|c|c|c|}
\hline & \multirow{2}{*}{ Biochemical parameters } & \multicolumn{2}{|c|}{ Codium tomentosum } \\
\hline & & Mediterranean sea & Red sea \\
\hline \multirow{6}{*}{$\begin{array}{l}\text { Antioxidants } \\
\text { compounds }\end{array}$} & Glycerol $\left(\mu \mathrm{M} \cdot \mathrm{g}^{-1} \mathrm{fw}\right)$ & $50.763 \pm$ & $64.540 .6 \pm$ \\
\hline & Proline $\left(\mu \mathrm{g} \cdot \mathrm{g}^{-1} \mathrm{fw}\right)$ & $2.070 .02 \pm$ & $2.490 .02 \pm$ \\
\hline & Total phenols (mg.g $\left.\mathrm{g}^{-1} \mathrm{fw}\right)$ & $0.39 \pm 0.01$ & $0.390 .03 \pm$ \\
\hline & Total flavonoids (mg.g $\mathrm{g}^{-1} \mathrm{dw}$ ) & $10.83 \pm 0.05$ & $2.93 \pm 0.1$ \\
\hline & Ascorbic acid (iM.g ${ }^{-1}$ fw) & $0.35 \pm 0.06$ & $0.54 \pm 0.01$ \\
\hline & Glutathione (mM.g $\left.\mathrm{g}^{-1} \mathrm{fw}\right)$ & $9.46 \pm 0.4$ & $9.780 .6 \pm$ \\
\hline \multirow{5}{*}{$\begin{array}{l}\text { Antioxidants } \\
\text { enzymes }\end{array}$} & (PPO) Amount of quinon. $\mathrm{g}^{-1}$ fw. $\mathrm{min}^{-1}$ & $0.690 .039 \pm$ & $1.2440 .06 \pm$ \\
\hline & (POX ) Amount of quinon. $\mathrm{g}^{-1}$ fw. $\min ^{-1}$ & $0.670 .004 \pm$ & $1.310 .12 \pm$ \\
\hline & (ASO) $\mathrm{mM}$ of ascorbate oxidized. $\mathrm{g}^{-1} \mathrm{fw} \cdot \mathrm{min}^{-1}$ & $18.270 .063 \pm$ & $18.760 .01 \pm$ \\
\hline & (APX) $\mathrm{mM}$ of ascorbate oxidized.g ${ }^{-1}$ fw. $\mathrm{min}^{-1}$ & $20.240 .115 \pm$ & $20.99042 \pm$ \\
\hline & (CAT) $\mu \mathrm{M}$ of $\mathrm{H}_{2} \mathrm{O}_{2}$ destroyed $\mathrm{g}^{-1}$ fw. $\mathrm{min}^{-1}$ & $0.400 .003 \pm$ & $0.4540 .2 .7 \pm$ \\
\hline \multirow{2}{*}{$\begin{array}{l}\text { Antioxidants } \\
\text { activity }\end{array}$} & Reducing power $\mu \mathrm{g} \cdot \mathrm{g}^{-1} \mathrm{dw}$ & $0.33 \pm 0.02$ & $0.95 \pm 0.06$ \\
\hline & Total antioxidant capacity (mg.g $\left.\mathrm{g}^{-1} \mathrm{dw}\right)$ & $126.625 .2 \pm$ & $230.0712 .3 \pm$ \\
\hline
\end{tabular}

Values (means \pm standard deviation of data for duplicated groups) for each site in the same column are significantly different at $5 \%$ level 
Results presented in Table 3 also showed variation in the antioxidant enzyme activities of Codium collected from both sites. The sample collected from Red Sea showed the greatest activity. However, (PPO) and (POX) recorded the maximum activities in Codium from site $\mathrm{R}$ (1.2 and 1.3 Amount of quinon. $\mathrm{g} \mathrm{fw}^{-1} \cdot \mathrm{min}^{-1}$, respectively) compared to the activities of both enzymes from site $\mathrm{M}$ (0.69 and 0.67 Amount of quinon. $\mathrm{g} \mathrm{fw}^{-1} \cdot \mathrm{min}^{-1}$, respectively). In addition, (ASO) and (APX) showed higher activities in R samples (18.8 and 20.9 ascorbate oxidized. $g$ $\mathrm{fw}^{-1} \cdot \mathrm{min}^{-1}$, respectively) compared to $\mathrm{M}$ samples (18.27 and 20.24 ascorbate oxidized. $\mathrm{g} \mathrm{fw}^{-1} \cdot \mathrm{min}^{-}$ ${ }^{1}$ respectively). Catalse (CAT) recorded also the maximum activity in Codium collected from the Red Sea $\left(0.45 \mu \mathrm{M}\right.$ of $\mathrm{H}_{2} \mathrm{O}_{2}$ destroyed.g $\left.\mathrm{fw}^{-1} \cdot \mathrm{min}^{-1}\right)$ in comparison with those from the Mediterranean Sea $\left(0.40 \mu \mathrm{M}\right.$ of $\mathrm{H}_{2} \mathrm{O}_{2}$ destroyed. $\left.\mathrm{g} \mathrm{fw}^{-1} \cdot \mathrm{min}^{-1}\right)$.

Electrophoretic profiles of total soluble protein of the two algal samples were shown in Plate 1. Gel scanning revealed to the appearance of 7 and 8 polypeptide bands in Codium from the two sites ( $\mathrm{M}$ and $\mathrm{R}$, respectively). Moreover, five common protein bands covering molecular weights ranged from 125 to $15 \mathrm{kDa}$ were detected in the two samples $(125,24,18,15$ and $8 \mathrm{kDa})$. However polypeptides with molecular weights 93, 72 and $42 \mathrm{kDa}$ were appeared only in Codium of site (M), whereas that of $17 \mathrm{kDa}$ was specific for Codium of site (R).

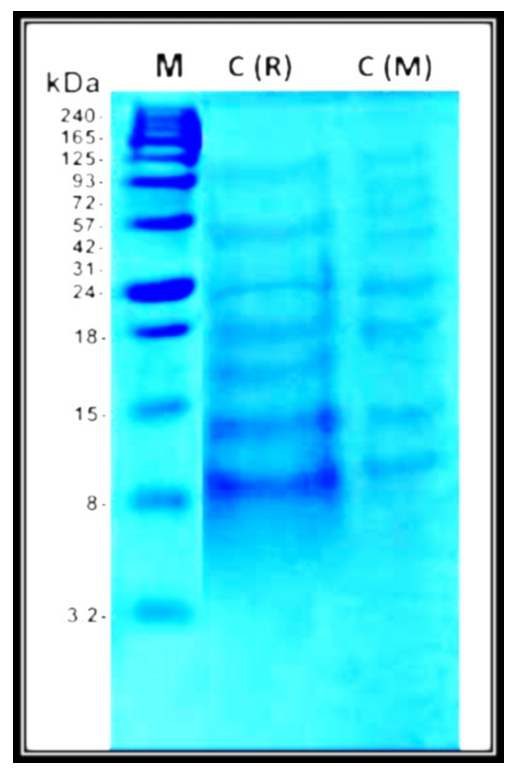

Plate 1. Changes in protein profiles of Codium tomentosum from two sampling sites; Red Sea (CR) and Mediterranean Sea (CM).
The electrophoretic analysis of protein pattern showed reduction in the relative concentration of certain polypeptides particularly those with molecular weights 15 and $8 \mathrm{kDa}$ in the Codium sample collected from site $\mathrm{M}$.

\section{Discussion}

Physico-chemical characteristics of the seawater with different climate, geology, and hydrology affect in great extent on the algal chemical composition and density of species in the surveyed area (Ibraheem et al., 2014). According to the current results, salinity and temperature of the Red Sea is relatively higher than those of the Mediterranean one. This high temperature may increases evaporation of water and consequently increases salinity of the water of Red Sea (Felis et al., 2000 and Gertman \& Brenner, 2004). However, salinity and temperature represents the dominant factors affecting both the local distribution (Leland et al., 2001) and growth of algae (Rao et al., 2007). Seaweeds alter their metabolism in extreme temperatures and salinity by producing a compatible solutes to organize proteins and cellular structures, maintain cell turgor by osmotic adjustment, and modify the antioxidant system to re-establish the cellular redox balance. (Janská et al., 2010 and Dennis, 2009). Strong difference in the carbohydrate content of both algal samples was observed in our study to elucidate the effect of site distribution on the chemical composition of Codium tomentosum. Sugars serve as osmo-adjustment, protect-ants and play a role in protecting cellular membranes from damage (Shao et al., 2006 and Yuanyuan et al., 2009). Soluble sugars are known to affect signal transduction and gene regulation mechanisms (Couée et al., 2005).

Soluble sugars are the main carbon skeletons of amino acids; the increase in soluble sugar was concomitant with sharp decrease in amino acids of Codium collected from the site R. Subsequently, amino acid metabolism might be shifted toward synthesis of sugars (Iraqi \& Tremblay, 2001). Meanwhile, the reduction in free amino acid contents in the sample of site $\mathrm{R}$ might be also attributed to the observed increase in glutathione. Hildebrandt et al. (2015) were reported that, the production of glutathione depends on the availability of amino acids.

Results revealed also that, the highest glycerol 
content was detected in the samples collected from site R of high salinity. This may be due to the protective effect of glycerol on the stability of PSII protein complexes as reported by Allakhverdiev et al. (2000). The observed increase in proline content of the sample collected from site R might be resulted from the enhancement of proline biosynthesis and/or decrease in its degradation (Kavikishore et al., 2005). Proline can act as a compatible osmolyte, thereby protecting cells from relative high salinity of Red Sea (Verbruggen \& Hermans, 2008 and Krasensky \& Jonak, 2012). Accumulation of proline has been implicated in the establishment and maintenance of thermotolerance against relative high temperature of the Red Sea compared to the Mediterranean one (Kakinuma et al., 2006 and D'souza \& Devaraj, 2013). Similar results on the thalli of Gracilaria corticata were obtained by Kumar et al. (2010), where salinity has accounted to an increase of almost two fold from the initial proline contents.

The observed increase in the mineral contents in the sample of Red Sea sit with relatively elevated salinity, greatly affects the homeostasis of the cell. This could be explained due to the antagonistic behavior of $\mathrm{Na}^{+}$and $\mathrm{K}^{+}$at the uptake sites which in turn impaired the ion selectivity and integrity of the cell membrane and permit the passive and excess accumulation of $\mathrm{Na}^{+}$in the thalli. The osmotic potential generated by high internal potassium concentrations can alleviate sodium toxicity (Maathuis, 2014).

Results showed more or less similar content of chlorophyll a value in Codium collected from the two sampling sites. Regardless to the site distribution, the total chlorophyll content was closely similar between the different regions. Similar results were obtained by Moustafa \& Saeed (2014) on Ulva fasciata collected from Ras Al-Tin and El-Muntazah from Alexandria shore at Egypt.

Fluctuations in salinity between the two sampling sites induce noteworthy alterations in antioxidant enzyme activities as well as stress metabolites in algae. According to the early literature data, marine algae, like other photosynthesizing plants, are exposed to a combination of environmental conditions that leads to the formation of free radicals. However, the absence of oxidative damage in the structural components of macro-algae suggests that their cells have protective anti-oxidative defense systems (Kelman et al., 2012 and Silva et al., 2017). All antioxidant enzymes of Codium from the two sites significantly increased in the sample of the site R. Some anti-oxidant enzymes were selected by Kumar et al. (2010) to evaluate the biochemical responses of the red alga Gracilaria corticata to salinity induced oxidative stress.

The current study also indicated that, there were no differences in the phenolic contents estimated in Codium collected from the two studied sites. This was concomitant by increased activity of PPO in the site R. Phenol is a substrate for PPO enzyme. Accordingly, the high activities of PPO have to reduce the accumulation of phenols which might be consumed as substrates (Taranto et al., 2017). Glutathione usually showed antioxidant property (scavenge the singles of oxygen, peroxide and hydroxyl radicals). However, it plays an important role in expression of defense genes and may be involved in the control of cell division (Shao et al., 2008). The observed increase in glutathione might be attributed to the accumulation of soluble sugars in Codium of sample R. Soluble sugars were hypothesized to act transcriptionally on the induction of cytosolic glucose-6-phosphate dehydrogenase (Hauschild \& Von Schaewer, 2003) which in turn provide NADPH required for GSH production. The central role of GSH in anti-oxidative defense is due to its ability to regenerate another powerful-water soluble antioxidant ascorbic acid (Foyer \& Noctor, 2001) which significantly increased in samples of $\mathrm{R}$ site. The relative high temperature and salinity of the Red Sea may stimulate the accumulation of ASO. Ascorbate oxidase can directly scavenge superoxide, hydroxyl radicals and singlet oxygen as well as reduce hydrogen peroxide to water via ascorbate peroxidase reduction (Caputo et al., 2010). According to the early literature data, the antioxidant capacity of algae (Ismail, 2017 and Srikong et al., 2017) is highly positively correlated with phenolics (Zubia et al., 2008) and flavonoids content (Sarojini et al., 2012). However, our study indicated that the increase in antioxidant capacity and reducing power (samples collected from the site $\mathrm{M}$ ) is not attributed to the redox properties of either phenols or the antioxidant enzymes but to the enhancement of flavonoid accumulation.

Scanning of the gel showed the de novo synthesize, over expression of some polypeptide chains in Codium from the two sites. However, 
data showed the appearance of polypeptides with molecular weights $17 \mathrm{kDa}$ was specific for samples collected from site R concomitant with the disappearance of it from samples collected from the site $\mathrm{M}$. The $17 \mathrm{kDa}$ protein functions as a molecular chaperone preventing protein denaturation under relative high temperature (Kim \& Ahn, 2009). However, the disappearance of protein bands of 93,72 and $42 \mathrm{kDa}$ in R site were in accordance with Kaur et al. (2009) who reported that heat acclimatized showed de novo synthesis of some low molecular proteins and the disappearance of some of existing proteins which failed to fold correctly and are generally degraded.

\section{Conclusion}

Codium is a source of many biologically functional substances which deserve attention due to their many health benefits. In this study, measurable differences in chemical composition were recorded between the two investigated strains of Codium in response to several environmental factors as temperature and salinity. Most of the environmental parameters vary according to season. Moreover, the changes in ecological conditions can stimulate or inhibit the biosynthesis of several nutrients.

Future work is needed to investigate the 'omic' profiling (integration of genomics and proteomics tools) to elucidate and understand diverse biochemical networks involved in cellular adaptation to different environmental factors according to different habitats sites.

Acknowledgements: Authors introduce all thankful and sincere gratitude to Prof. Dr. Abd El-Salam Mohamed Shaaban, Professor of Phycology, Botany Department, Faculty of Science, Ain Shams University, for his great help and supports.

\section{References}

Aleem, A.A. (1993) "The Marine Algae of Alexandria, Egypt". University of Alexandria Publications, pp. 138. (Privately published).

Allakhverdiev, S.I., Sakamoto, A., Nishiyama, Y., Inaba, M. and Murata, N. (2000) Ionic and osmotic effects of $\mathrm{NaCl}$-induced inactivation of photosystems I and II in Synechococcus sp. Plant Physiol. 123(3), 1047-1056.
Ashraf, M. and Foolad, M.R. (2006) Roles of glycine betaine and proline in improving plant abiotic stress resistance. Environ. Exp. Bot. 59, 206-216.

Bates, L.S., Waldren, R.P. and Tear, I.D. (1973) Rapid determination of free proline for water-stress studies. Plant and Soil, 39, 205-207.

Blakeney, A.B. and Mutton, L.L. (1980) A simple calorimetric method for the determination of sugars in fruits and vegetables. J. Sci. Food Agri. 31, 889-897.

Bradford, M.M. (1976) A rapid and sensitive method for the quantification of microgram quantities of protein utilizing the principle of protein dye binding. Anal. Biochem. 72, 248-254.

Caputo, E., Ceglie, V., Lippolis, M., La Rocca, N. and De Tullio, M.C. (2010) Identification of a $\mathrm{NaCl}$-induced ascorbate oxidase activity in Chaetomorpha linum suggests a novel mechanism of adaptation to increased salinity. Environ. Exp. Bot. 69, 63-7.

Chen, Y., Cao, X.D., Lu, Y. and Wang, X.R. (2000) Effects of rare earth metal ions and their EDTA complexes on antioxidant enzymes of fish liver. Bull. Environmental Contamin Toxicol. 65, 357-365.

Couée, I., Sulmon, C., Gouesbet, G. and El-Amrani, A. (2005) Involvement of soluble sugars in reactive oxygen species balance and responses to oxidative stress in plants. J. Exp. Bot. 1-11.

D'souza, M.R. and Devaraj, V.R. (2013) Induction of thermos-tolerance through heat acclimation in lablab bean (Dolichos lablab). Afri. J. Biotechnol. 12(38), 5695-5704.

Daughaday, W.H., Lowry, O.H., Rosebrough, N.J. and Fields, W.S. (1952) Determination of cerebrospinal fluid protein with the folin phenol reagent. J. Lab. Clinic. Med. 39(4), 663-665.

Dennis, K.E., Aschner, J.L., Milatovic, D., Schmidt, J.W., Aschner, M. and Kaplowitz, M.R. (2009) NADPH oxidases and reactive oxygen species at different stages of chronic hypoxia-induced pulmonary hypertension in newborn piglets. Amer. J. Physiol-Lung Cell and Molec. Physiol. 297(4), 596-607.

Diallinas, G., Pateraki, I., Sanmartin, M., Scossa, A., 
Stillianou, E., Panopoulos, N.J. and Kanellis, A.K. (1997) Melon ascorbate oxidase: Cloning of a multigen family, induction during fruit development and repression by wounding. Plant Molec. Biol. 34, 759-770.

Dorman, H., Kosar, M., Kahlos, K., Holm, Y. and Hiltunen, R. (2003) Antioxidant properties and composition of aqueous extracts from Mentha species, hybrids, varieties, and cultivars. J. Agri. Food Chem. 51, 4563-4569.

El-Said, G.F. and El-Sikaily, A. (2013) Chemical composition of some seaweed from Mediterranean Sea coast, Egypt. Enviro. Monitor. and Asses. 185 (7), 6089-6099.

Farghaly, M.S. and El-Shoubaky, G.A. (2015) Synopsis of biodiversity and distribution of macrophytes along the Suez Canal in time and space. International Conference on Plant, Marine and Enviro. Sci. 2, pp. 115-120.

Felis, T., Pätzold, J., Loya, Y., Fine, M., Nawar, A.H. and Wefer, G. (2000) A coral oxygen isotope record from the northern Red Sea documenting NAO, ENSO, and North Pacific teleconnections on Middle East climate variability since the year 1750 . Paleoceanography, 15(6), 679-694.

Foyer, C.H. and Noctor, G. (2001) The molecular biology and metabolism of glutathione. In: "Significance of Glutathione in Plant Adaptation to the Environment", Grill, D., M. Tausz, L.De KoK (Ed.), pp. 27-57. The Netherlands: Kluwer Academic Publishers.

Gertman, I. and Brenner, S. (2004) Analysis of water temperature variability in the Gulf of Eilat - IET Project no. 12. In: Evaluation of Fish Cages in the Gulf of Eilat, a technical report for the Israeli Ministries of Infrastructure Environment and Agriculture, (Ed.): Atkinson, M. J., Y. Birk \& H. Rosenthal.

Harborne, J.B. (1998) "Photochemical Methods: A Guide to Modern Technique of Plant Analysis", $3^{\text {rd }}$ ed. Champman and Hall, London, UK, p. 302.

Hauschild, R. and von Schaewen, A. (2003) Differential regulation of glucose-6-phosphate dehydrogenase isoenzyme activities in potato. Plant Physiol. 133, 47-62.
Hildebrandt, T.M., Nesi, A.N., Araújo,W.L. and Braun, H.P. (2015) Review article: Amino Acid Catabolism in Plants. Mol. Plant, 8(11), 1563-79.

Hissin, P.J. and Hilf, R. (1976) A Fluor metric method for determination of oxidized and reduced glutathione in tissues. Ann. Biochem. 74, 214-226.

Homme, P.M., Gonalez, B. and Billard, J. (1992) Carbohydrate content, fructane and sucrose enzyme activities in roots, stubble and leaves of rye grass (Lolium perenne L.) as affected by source/sink modification after cutting. J. Plant Physiol. 140, 282-291.

Ibraheem, I.B.M., Alharbi, R.M., Abdel-Raouf, N. and AlEnazi, N.M.(2014) Contributions to the study of the marine algae inhabiting Umluj Seashore, Red Sea. Beni-suef Univ. J. Basic Appli. Sci. 3, 278-285.

Iraqi, D. and Tremblay, F.M. (2001) The role of sucrose during maturation of black spruce [Picea mariana (Mill.) BSP) and white spruce [Picea glauca (Moench) Voss] somatic embryos. Physiol. Plant. 111, 381-388.

İrkin, L.C. and Erduðan, H. (2014) Chemical composition of Ulva rigida C. Agardh from the Çanakkale Strait (Dardanelles). Turkey. J. Black Sea/Mediter. Enviro. 20(2), 114-121.

Ismail, G.A. (2017) Biochemical composition of some Egyptian seaweeds with potent nutritive and antioxidant properties. Food Sci. Technol. Campinas, 37(2), 294-302.

Jackson, W.A. and Thomas, G.W. (1960) Effect of KCl and dolometric limestone on growth and ion uptake of sweet potato. Soil Sci. 89, 347-352.

Janská, A., Maršík, P. Zelenková, S. and Ovesná, J. (2010) Cold stress and acclimation-what is important for metabolic adjustment? Plant Biol. 12 (3), 395-405

Kakinuma, M., Kaneko, I., Coury, D.A., Suzuki, T. and Amano, H. (2006) Isolation and identification of gametogenesis-related genes in Porphyra yezoensis (Rhodophyta) using subtracted cDNA libraries. $J$. Appl. Phycol. 18, 489-496.

Kar, M. and Mishra, D. (1976) Catalase, peroxidase and polyphenol oxidase activities during rice leaf senescence. Plant Physiol. 57, 315-319. 
Kaur, P., Ghai, N. and Sangha, M.K. (2009) Induction of thermotolerance through heat acclimation and salicylic acid in Brassica species, Afr. J. Biotechnol. 8(4), 619-625.

Kavikishore, P.B., Sangam, S., Amrutha, R.N., Laxmi, P.S., Naidu, K.R., Rao, K.R., Rao, S., Reddy, K.J., Theriappan, P. and Sreenivasulu, N. (2005) Regulation of proline biosynthesis, degradation, uptake and transport in higher plants: Its implications in plant growth and abiotic stress tolerance. Curr. Sci. 88, 424-438.

Kelman, D., Posner, E.K., McDermid, K.J., Tabandera, N.K., Wright, P.R. and Wright, A.D. (2012) Antioxidant activity of Hawaiian marine algae. Mar. Drugs, 10, 403-416.

Kim, H. and Ahn, Y.J. (2009) Expression of a gene encoding the carrot HSP17.7 in Escherichia coli enhances cell viability and protein solubility under heat stress. Hort. Sci. 44, 866-869.

Kochert, G. (1978) Carbohydrate determination by the phenol-sulfuric acid method. In: "Handbook of Phycological Methods: Physiological and Biochemical Methods", pp. 95-97. London: Cambridge University Press.

Koricheva, J., Roy, S., Vranjic, J.A., Haukioja, E., Hughes, P.R. and Hanninen, O. (1997) Antioxidant responses to simulated acid rain and heavy metal deposition in brich seedlings. Enviro. Pollut. 95, 249-258

Krasensky, J. and Jonak, C. (2012) Drought, salt, and temperature stress-induced metabolic rearrangements and regulatory networks. J. Exp. Bot. 63(4), 1593-1608.

Kumar, M., Kumari, P., Gupta, V., Reddy, C.R.K. and Jha, B. (2010) Biochemical responses of red alga Gracilaria corticata (Gracilariales, Rhodophyta) to salinity induced oxidative stress. J. Exp. Marine Biol. Ecol. 391(1), 27-34.

Laemmli, U.K. (1970) Cleavage of structural proteins during the assembly of the head of bacteriophage T4. Nature, 227, 680-685.

Lambert, M. and Neish, A.C. (1950) Rapid method for estimation of glycerol in fermentation solutions. Can. J. Res. 28, 83-89.

Leland, H.V., Brown, L.R. and Mueller, D.K. (2001) Distribution of algae in the San Joaquin River,
California, in relation to nutrient supply, salinity and other environmental factors. Freshwater Biol. 46, 1139-1167.

Loiseaux-de Goër, S. and Noailles, M.C. (2008) "Algues de Roscoff". pp. 1-215, Col. Figs. Roscoff: Editions de la Station Biologique de Roscoff.

Maathuis, F.J.M. (2014) Review article: Sodium in plants: perception, signalling, and regulation of sodium fluxes. Journal of Experimental Botany, $\mathbf{6 5}$, 3, 849-858.

Malik, C.P. and Singh, M.B. (1980) In: "Plant Enzymology and Histo-enzymology", pp. 286. Kalyani Publishers. New Delhi.

Mansour, H.A., Emam, M.A., Emam, M.M., Shaaban, A.M. and. Mostafa, N.H. (2017) Gene over expression of glycerol-3-phosphate dehydrogenase in some marine algae of Egypt. Egypt. J. Bot. 57(1), $31-48$.

Messyasz, B. and Rybak, A. (2010) Abiotic factors affecting the development of Ulva sp. (Ulvophyceae, Chlorophyta) in freshwater ecosystems. Aquat. Ecol. 45, 75-87.

Metzner, H., Rau, H. and Senger, H. (1965) Uentersuchungen Zur Synchronisier barkeit einzelner-pigment. Mangol Mutanten Von Chloella. Planta, 65(2), 186-194.

Mostafa, N.H. (2016) Biochemical evaluation on some oligohalopic and euhalopic algae from Egypt. $M$. Sc.Thesis. Fac. Sci., Ain Shams Uni., Egypt, 139pp.

Moustafa, Y.T. and Saeed, S.M. (2014) Nutritional evaluation of green macro-algae, Ulva sp. and related water nutrients in the southern Mediterranean Sea Coast, Alexandria shore, Egypt. $4^{\text {th }}$ Conference of Central Laboratory for Aquaculture Research, pp. 35-55.

Mukherjee, S.P. and Choudhuri, M.A. (1983) Implications of water stress-induced changes in the levels of endogenous ascorbic acid and hydrogen peroxide in Vigna seedlings. Physiol. Planta, 58, 166-170.

Naguib, M.I. (1963) Colourimetric estimation of plant polysaccharides. Zeit-Zucher, 16, 15-22.

Ortiz, J., Romero, N., Robert, P., Araya, J., Lopez- 
Hernández, J., Bozzo, C.E., Navarrete, C.E., Osorio, A. and Rios, A. (2006) Dietary fiber, amino acid, fatty acid and tocopherol contents of the edible seaweeds Ulva lactuca and Durvillaea antarctica. Food Chem. 99, 98-104.

Oyaizu, M. (1986) Studies on product of browning reaction prepared from glucose amine. Jpn. J. Nutr. 44, 307-15.

Ranganna, S. (1977) "Manual Analysis of Fruits and Vegetables Products". New Delhi: Mc Grow-Hill Publishing Company, pp. 363.

Rao, A.R., Dayananda, C., Sarada, R., Shamala, T.R. and Ravishankar, G.A. (2007) Effect of salinity on growth of green alga Botryococcus braunii and its constituents. Biores. Technol. 98(3), 560-564.

Robledo, D. and Pelegr'ýn, Y.F. (1997) Chemical and mineral composition of six potentially edible seaweed species of Yucat'an, Bot. Mar. 40(1-6), 301-306.

Sarojini, Y., Lakshminarayana, K. and Rao, P.S. (2012) Variations in distribution of flavonoids in some seaweed of Visakhapatnam coast of India. Der. Pharma. Chemica. 4(4), 1481-1484.

Shao, H., Chu, L., Jaleel, C.A. and Zhao, C. (2008) Water-dePcit stress-induced anatomical changes in higher plant. C.R. Biologes. 331, 215-225.

Shao, H.B., Liang, Z.S. and Shao, M.A. (2006) Osmotic regulation of 10 wheat (Triticum aestivum L.) genotypes at soil water deficits. Biointer, 47, 132-139.

Silva, A.M.O., Novoa, A.V., Gutierrez, D.D. and Mancini-Filho, J. (2017) Seaweeds from Halimeda genus as sources of natural antioxidants. J. Anal. Pharm. Res. 5(6), 1-5.
Srikong, W., Bovornreungroj, N., Mittraparparthorn, P. and Bovornreungroj, P. (2017) Antibacterial and antioxidant activities of differential solvent extractions from the green seaweed Ulva intestinalis. Science Asia, 43, 88-95.

Taranto, F., Pasqualone, A., Mangini, G., Tripodi, P., Miazzi, M.M., Pavan, S. and Montemurro, C. (2017) Review: Polyphenol oxidases in crops: Biochemical, physiological and genetic aspects. Int. J. Mol. Sci. 18, 377-393.

Van den Hoek, C. (1984) World-wide latitudinal and longitudinal seaweed distribution patterns and their possible causes, as illustrated by the distribution of Rhodophytan genera. Helgoländer Meeresuntersuchungen, 38(2), 227-257.

Verbruggen, N. and Hermans, C. (2008) Proline accumulation in plants: A rev. Amino Acids, 35, 753-759.

Wasfi, M.A.R. (1970) Influence of fertilizers on the chemical composition of tobacco. M.Sc. Thesis, University of Khartoum, Khartoum Sudan.

Yuanyuan, M., Yali, Z., Jiang, L. and Hongbo, S. (2009) Roles of plant soluble sugars and their responses to plant cold stress. Afri. J. Biotechnol. 8(10), 2004-2010.

Zubia, M., Payri, C. and Deslandes, E. (2008) Alginate, mannitol, phenolic compounds and biological activities of two range-extending brown algae, Sargassum mangarevense and Turbinaria ornate (Phaeophyta: Fucales), from Tahiti (French Polynesia). J. Appl. Phycol. 20, 1033-1043.

(Received 23/11/2017; accepted 3 / 4 /2018) 


\section{تأثير البيئات المختلفة على المحتوى الكميائى للكوديوم تومينتوسوح}

هدي انور منصور، منال محمد امام و نعمات حسن مصطفي

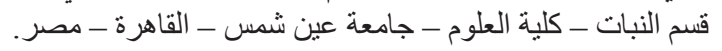

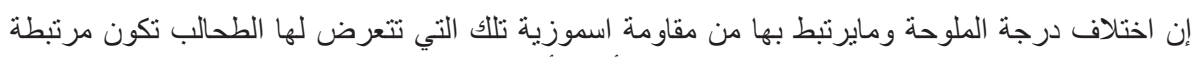

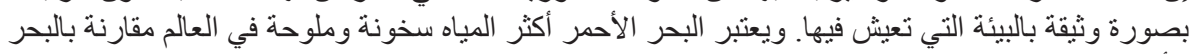
الأبيض المتوسط.

ولذلك تهدف هذه الدراسة إلى تقييم التركيب الكيميائي والقدرة الكلية لمضادات الأكسدة لطحلب الكوديح

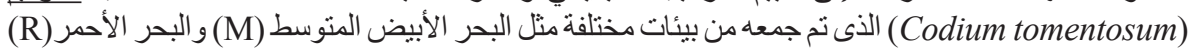

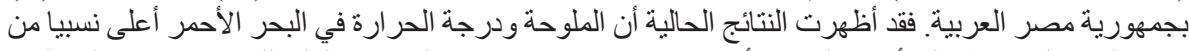

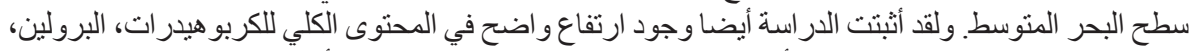

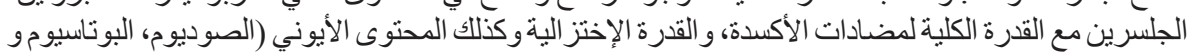

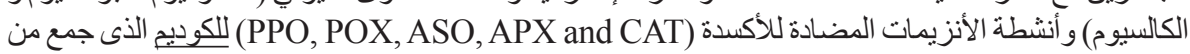

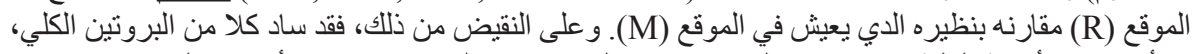

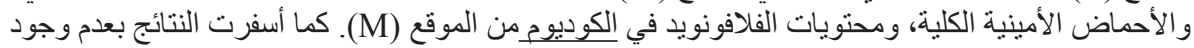

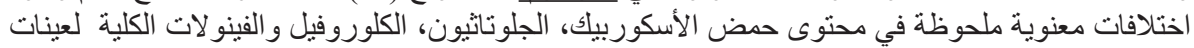

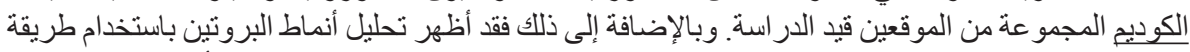

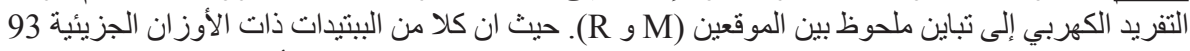

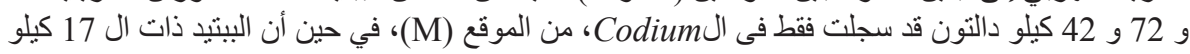

دالتون ظهر فقط فى ال Codium من الموقع (R) فئون

وفي هذا المقام يمكننا القول أن الأرتفاع النسبي للملوحة وكذلك درجة الحرارة في الموقع R مقارنه بالموقع

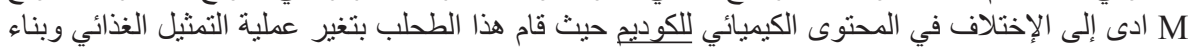

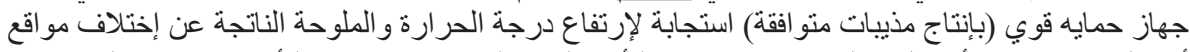

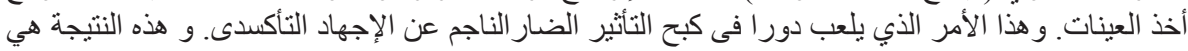

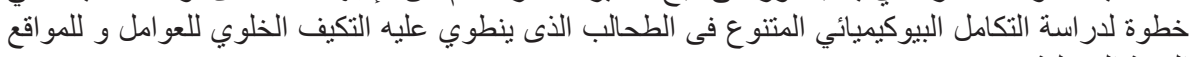

البيئية المختلفة. 